\title{
Flood Study of Wainganga River in Maharashtra Using GIS \& Remote Sensing Techniques
}

\author{
Ravindra S. Bhagat ${ }^{1}$, Dr. Devendra K. Bisen ${ }^{2}$ \\ ${ }^{1}$ Head, Department of Geography, SahebraooShankarraoDhamdhere Arts \& Commerce College, Talegaon Dhamdhere, Tal- Shirur, Dist- \\ Pune 412208
}

${ }^{2}$ Head, Department of Geography, M. B. Patel Arts, Commerce \& Science College, Deori, Dist. Gondia

\begin{abstract}
In the past, there have been several climatic parameters occurring in most part of the earth due to climate changesuch as intensity of rainfall, cloudburst, heavy rainfall etc. Flood is a one of the natural calamities occurring from time to time and space to space in all rivers, which not only damages natural resources and the lives but also causes the loss of economy and human being. So I have attempt to made in the Mapping of flood impact of Wainganga river basin in Maharashtra based on using remote sensing and GIS techniques. So the prepare from such calamity, vulnerable areas for flood affection area a need to find out. Therefore, in this research paper try to made find out the flood prone areas by using remote sensing and GIS techniques. To get the demarcation of flood line with the help of Grid rainfall data. With the help of such information identifies flood prone areas and will help in river management.
\end{abstract}

Keywords: Wainganga river basin, Grid rainfall, Flood impact map, GIS, remote sensing.

\section{Introduction}

When rivers overflow their banks they cause damage to lives, property, infrastructure and crops. Rivers can also flood its surroundings when the when ice or a landslide temporarily block the course of the river channel, dams fail etc. The rivers bring heavy sediment load from the catchments. Inadequate carrying capacity of the rivers is responsible for causing floods, drainage congestion and erosion and deposition of river-banks. The Impact of flood map for the study area identifies flood prone areas that will help in river management and appropriate planning of development works. Eighty per cent of the precipitation takes place in the monsoon months from June to September. The Wainganga sub-basin is naturally prone to flooding, with floods being recorded every 5-7 years. Recently the Wainganga basin has experienced floods in 2001, 2004, 2007 and 2013.

\section{Study Area}

The Wainganga River rises atEl $640.0 \mathrm{~m}$ in the Seoni District of Madhya Pradesh from the Western slopes of Maikala Ranges which is continuation of the Satpura Ranges in Central, India. The Wainganga River receives numerous tributaries on either bank and drains the western, central and eastern regions of the Chandrapur, Gadchiroli, Bhandara, Gondia and Nagpur districts of Maharashtra.

(Latitude extension- $1^{0} 30^{\prime} N$ to $2^{0} 30$ N'\& Longitude extension- $7^{0} 00^{\prime} \mathrm{E}$ to $80^{\circ} 30 \mathrm{E}$ ')

It is joined by the Wardha River at a place called Gundapet flowing from the west, draining the major portion of the Maharashtra Plateau. Thereafter the river is known as Pranhita River. The climate of the sub-basin is characterized by hot summer from March to May with rainy season from June to September although the area has some rains in post monsoon season also. The Prahnita River joins the Godavari River on the left bank which drains the Eastern Coast in
Andhra Pradesh and flows out to the Bay of Bengal. The Wainganga River receives numerous tributaries on either bank and drains the western, central and eastern regions of the Chandrapur, Gadchiroli, Bhandara, Gondia and Nagpur districts of Maharashtra.

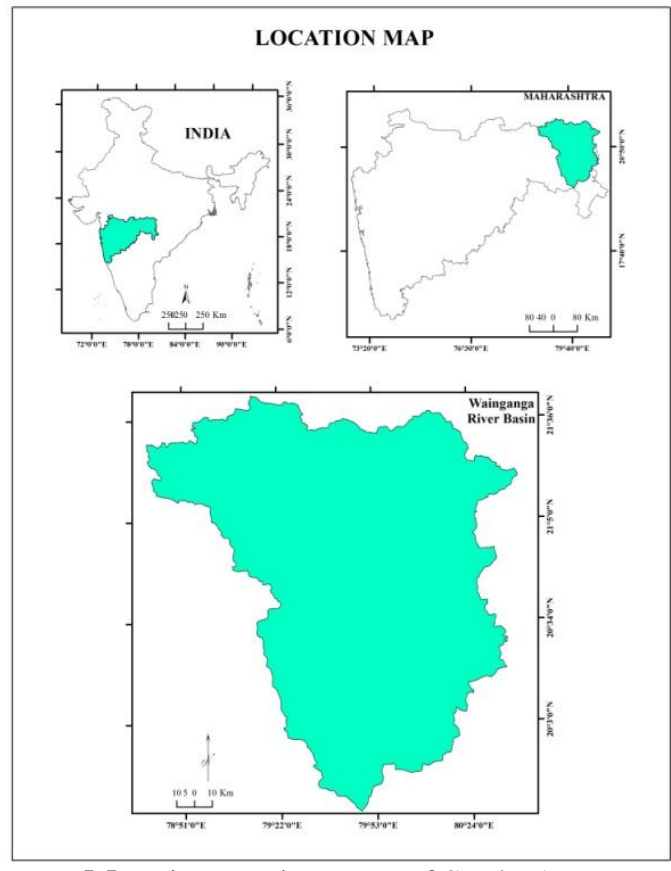

Map 1: Location Map of Study Area

\section{Material and Methods}

For the present studies of flood analysis data have obtained from one inch topographic map of Survey of India (1:63,360 or $1: 2,50,000)$. They are toposheet No. 55K, 55O, 55P, 56M, 64C, 64D, 65A.Includes sorting of data, digitization of various layers, preparation of maps, statistical analysis and other GIS/RS techniques, like Georeferencing, Data attachment, area calculation. The various maps were formed using ArcGIS and ERDAS imagine software. The rainfall distribution map was prepared from Indian Metrological 


\section{International Journal of Science and Research (IJSR) \\ ISSN (Online): 2319-7064 \\ Index Copernicus Value (2013): 6.14 | Impact Factor (2015): 6.391}

Department (IMD) $0.25^{\circ}$ to $0.25^{\circ}$ grid data. The thematic maps of rainfall distribution, slope, and micro watershed size, drainage density, soil type and land use/land cover per micro watershed were prepared using ArcGIS software and assigned weightage for each class. And then finally, integrated Flood Impact map was prepared.

\section{Literature Review}

Several studies related with different aspects of Flood analysis of river have been carried out from different parts of the country and abroad.

Kale V.S.(1999): He emphasized on causes and consequences of flood in major Indian river systems of North and eastern India

Rana Narendra Kumarand Tyagi Nutan(2008): Hedemarcate flood prone are a identified three different risk zones based on physical exposure of the area to flood and nature and extent of human vulnerability.

Paranjpye Vijay (2013): The report "Master Plan for Integrated Development and Management of Water Resources of Wainganga Sub- Basin". Gives guidelines on important issues regarding river system and its work process.

Ajin, et al., (2011) has carried out a study to prepare Flood hazard risk zone maps of Vamanapuram River basin based on using GIS \& RS tools. The factors such as rainfall distribution, drainage density, land use, soil type, slope etc. are studied to prepare Flood hazard risk zone map.

\section{Results and Discussions}

\subsection{Land use Land Cover}

Land use land cover is most important factor that causes the flood hazard. The Wainganga distribution of land use land cover classes of image include rocky land /open space, dense Forest, water bodies, agriculture, sparse vegetation, fallow land, open Scrub, barren land, settlement, gravel land. The major land use categories in the Wainganga River's basin includes build up land (1.89\%) and agricultural land (14.17\%) that comprises of generally kharif, rabi and double crop system in the region.For Agricultural land the presence of thick vegetation cover slows the journey of water from sky to soil and reduces amount of runoff. Forest cover (65.75\%) comprises of dense forest $(15.03 \%)$, sparse vegetation (23.01\%), open Scrub (27.71\%) and recent plantations. Deciduous or dense forest largely spreads out in the region in the east of the all Wainganga river basin area. Forest cover comprises of deciduous forests, degraded forests, forest blanks and recent plantations. Barren land consists of soil in which plants cannot grow results in increasing runoff on the other side fallow land causes destruction to free flow of runoff. Water Bodies (2.11\%), barren Land (9.48\%), fallow Land (4.19\%), gravel Land (0.52\%), rocky Land or open Space $(1.88 \%)$ can also be found in the region. Waste land with or without scrub and barren rocky/stony waste can also be found in the region. A supervised classification method was adopted using ERDAS
Imagine software and later analyzed using ArcGIS spatial analyst tools.

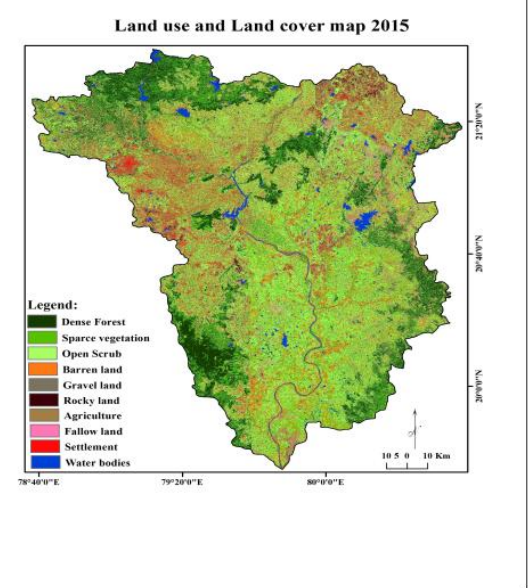

Map 2: Land Use map of Wainganga sub-basin

\subsection{Soil type}

For flood hazard zonation soil type is a most important factor as the amount of water flow through soil is depends on infiltration capacity and the remaining results in to the surface runoff. Different types of soil can be found in the Wainganga river basin, which directly influence the kind of agricultural practices followed. Similarly the information on soil types was obtained from Survey of India toposheet and National Bureau of Soil Survey and Land use Planning. It is shown from Map 3, that the majority of the study area is consists of the soils of the Wainganga sub-basin is sub type of soil 45 dominate as the principal soil types of the study area. The chances of flood increase with decrease in infiltration capacity.

\subsection{Morphometry control on flood}

According to Strahler's scheme of Stream Ordering in Wainganga basin is $7^{\text {th }}$ order drainage basin and total stream 4870 that included $1^{\text {st }} 3318,2^{\text {nd }}$ order $1117,3^{\text {rd }}$ order $331,4^{\text {th }}$ order $88,5^{\text {th }}$ order $11,6^{\text {th }}$ order 4 stream. The Wainganga River basin total means Bifurcation Ratio is 3.55 that is a natural river system where uniformity is seen with respect to climate, rock type and stage of development. The number of streams of a given order in a drainage basin systematically with increasing stream order and to reach up number of segments is 2786.1. In the Wainganga River having sinuosity index more than 1.41 is defined as meandering. Drainage basin geometry shape mainly in sub basin of Wainganga is dendritic to dendritic type. The Wainganga River sub-basin drainage density is Coarse (drainage density 0.70). Stream frequency is the measure of number of stream per unit area so it's having $0.18 \mathrm{~km}^{2}$. This value is low which indicates the basin is highly thick vegetative cover and permeable sub soil.

\subsection{Rainfall distribution}

The rainfall data of these stations were collected from IMD and the rainfall maps was prepared using 49 Grid stations and prepare spatial and temporal rainfall map form collected 


\section{International Journal of Science and Research (IJSR) \\ ISSN (Online): 2319-7064 \\ Index Copernicus Value (2013): 6.14 | Impact Factor (2015): 6.391}

IMD .Rainfall distribution is important factor for flood hazard zonation. High intensity rainfall is results into heavy floods. Floods occur when the volume of water exceeds the ability of a stream and river to hold the water within its normal banks. Gridded rainfall data of $0.25^{\circ} \times 0.25^{\circ}$ resolution was analyzed to annual and seasonal scales in Wainganga river basin located in Maharashtra during 1961 to 2014. Only 1972,1974,1984,1987,1991,1996,2004 years has a significant decreasing trend during 1961-2014. During the study period, overall a 1972 decrease in annual rainfall is found. The most probable year of highly rainfall change was found to be 1992 in annual and monsoonal rainfall. There is an increasing rainfall trend in the basin during the period 1961, 1975, 1978,1990,1992,1994,2001,2005,2007 and 2013.

\section{Spatial Distribution}

This space variation is accounted in fact by working out to use Isohyet method. This variation found in Grid $20.25^{0}$ to $80.25^{\circ}$ have highest rainfall $1059.38 \mathrm{~mm}$ and in the $20.00^{\circ}$ to $80.25^{\circ}$ lowest rainfall is $640.57 \mathrm{~mm}$ in the year of 1961 to 1970. In the 1971 to 1980 decade found of the highest rainfall $1001.31 \mathrm{~mm}$ in $21.75^{\circ}$ to $80.00^{\circ}$ grids and also $640.57 \mathrm{~mm}$ lowest rainfall occurs reference to grid $20.75^{\circ}$ to $80.25^{\circ}$. In the decade of 1981 to 1990 highest rainfall is $1097.10 \mathrm{~mm}$ and lowest rainfall $672.44 \mathrm{~mm}$ in $21.50^{\circ}$ to $80.00^{\circ}$ and $21.25^{\circ}$ to $80.50^{\circ}$ respectively. The recent 24 years the maximum rainfall $1248.46 \mathrm{~mm}$ and minimum rainfall $616.56 \mathrm{~mm}$ found that area $21.50^{\circ}$ to $80.00^{\circ}$ and $21.75^{\circ}$ to $78.50^{\circ}$.
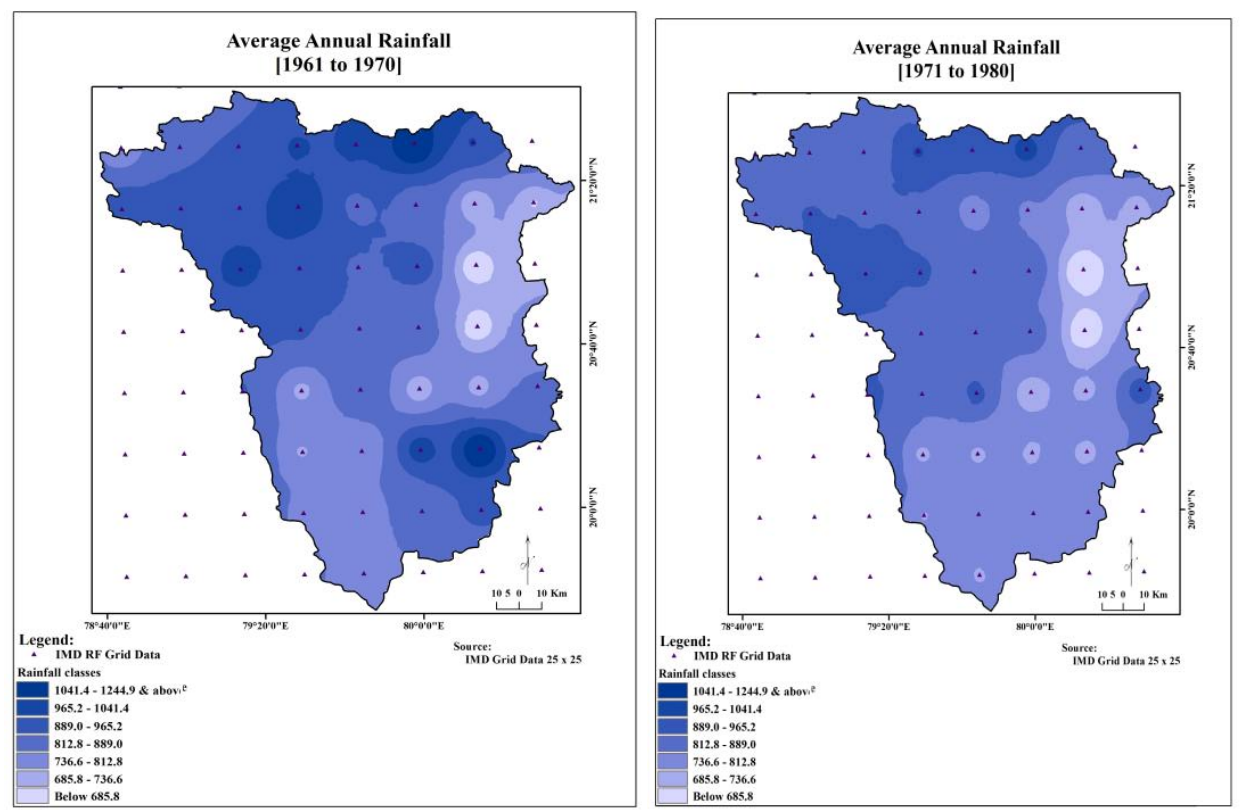

Map 3: Average Auuaal Rainfall in the Wainganga Sub-basin (1961 - 1970 \& 1971 - 1980)
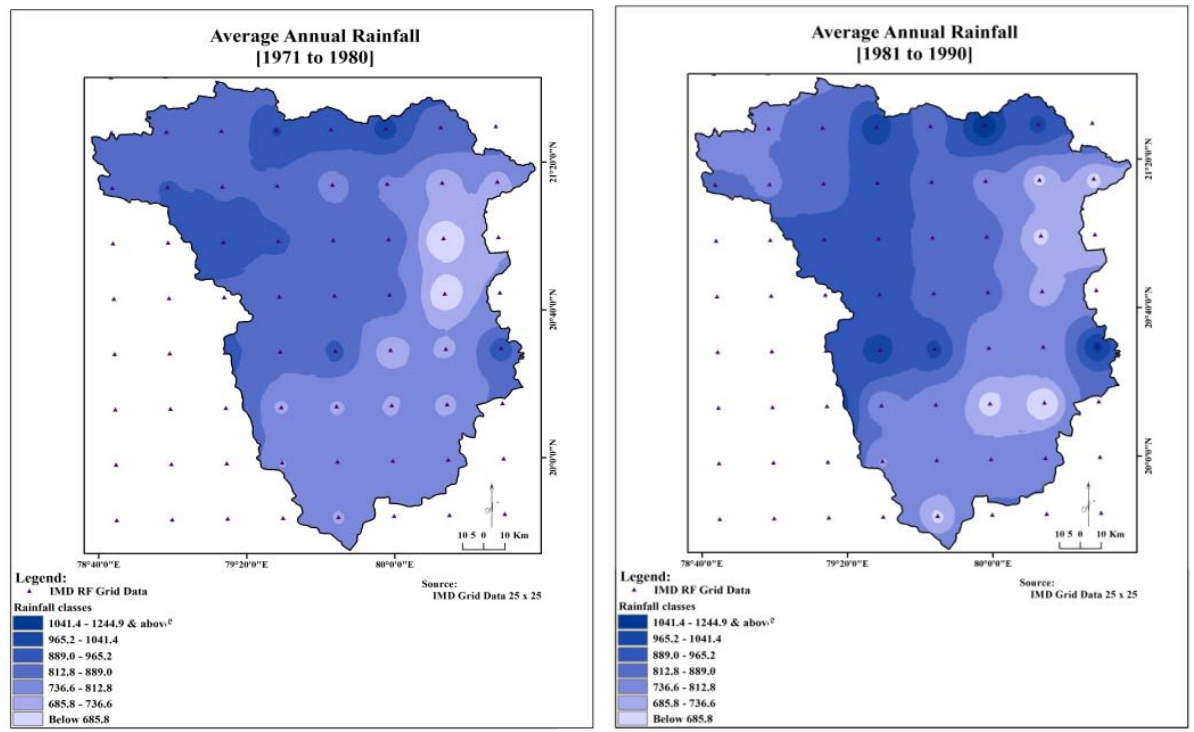

Map 4: Average Auuaal Rainfall in the Wainganga Sub-basin (1961 - 1990 \& 1991 - 2014)

\subsection{Impact of Flood Line on Wainganga River}

The GIS technique has been used to obtain the flood impact map of Bhandara, Nagpur, Gondia, Chandrapur and
Gadchiroli district. The flood impact map has been classified into two classes from the study of rainfall data i.e above rainfall of $1200 \mathrm{~mm}$ and $600 \mathrm{~mm}$. The high risk zone area covers part along the whole Wainganga River. Flood line 


\section{International Journal of Science and Research (IJSR) \\ ISSN (Online): 2319-7064 \\ Index Copernicus Value (2013): 6.14 | Impact Factor (2015): 6.391}

demarcation plays important role in the villages and cityIn the flood year of the during 1961 to 2014 in Gondia district 188 villages have been affected by the floods and its cover the area of $336.35 \mathrm{~km}^{2}$. In the same year 102 villages impact of flood in the Chandrapur district. 147 villages have been affected by the floods in Gadchiroli district and its cover the area of $254.11 \mathrm{~km}^{2}$. In Nagpur district and around the Wainganga River $322.13 \mathrm{~km}^{2}$ areasaffected by the flood and near about 148 villages are continuously under the flood. Flood Impact map give us an idea of highest flood level in the flood prone area, which helps to understand channel changes in the study region.

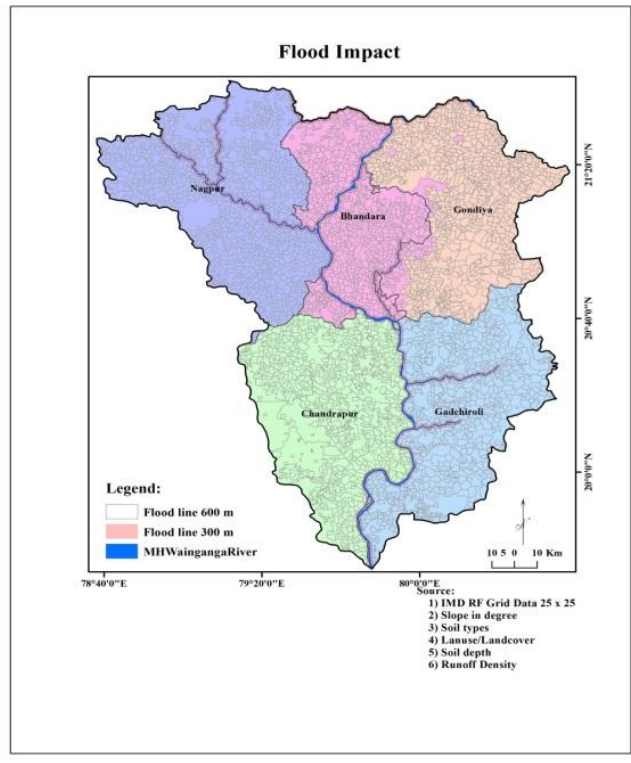

Map 5: Flood Impact of Wainganga River

\section{Conclusion}

This study envisioned to demarcate the flood line and impact of risk zone areas Wainganga river basin by using Survey of India toposheet, Cartosat DEM and satellite data. GIS technology is being used to identify the danger zones for flood vulnerability. The result from the study can be useful to the people residing in the villages which are prone. The study concluded that the extreme water accumulation in the basin in association with abrupt occurrence of surplus rainfall is the key cause for flash flood existence. Therefore, the potential flood risk area need to take into consideration for any type of disaster and preparedness plan and prewarning notice. This will empower individuals and officials to take suitable preliminary and response measures, which will help them for taking decision.

\section{References}

[1] Muhammad Ismail and IyortimOpeluwaSaanyol, (2013), Application of Remote Sensing (RS) and Geographic Information Systems (GIS) in flood vulnerability mapping: Case study of River Kaduna, International Journal of Geomatics and Geosciences, 3, pp 3.

[2] Thilagavathi, G., Tamilenthi, S., Ramu, C. and Baskaran, R., (2011), Application of GIS in flood hazard zonation studies in papanasamtaluk, thanjavur district, tamilnadu, Advances in Applied Science Research, 2 (3), pp 574585.
[3] Sneh., Gangwar.,"Flood Vulnerability in India: A Remote Sensing and GIS Approach for Warning, Mitigation and Management", International Journal of Environmental Science: Development and Monitoring (IJESDM) ISSN No. 2231-1289, Volume 4 No. 2., pp.,77-79,2013.

[4] Central Water Commission Report, "Role of remote sensing and GIS in Flood Management". New Delhi 2012

[5] Panda.,P.," vulnerability of flood in india: a remote sensing and GIS approach for warning, mitigation and management"., Asian Journal of Science and Technology Vol. 5, Issue 12, pp.843-846,2014

[6] Hire P.S. (2000) "Geomorphic and Hydraulic studies of floods in Tapi Basin published Ph.D.

[7] Baker V.R. (1984), flood sedimentation in bedrock fluvial systems, men-can Soc. Pet Geo. 10, 87-98. 